\title{
PENGARUH SIKAP TAWAKAL TERHADAP KESTABILAN EMOSI SISWA MADRASAH ALIYAH NEGERI 1 METRO
}

\author{
Oleh. \\ Sri Andri Astuti \\ Institut Agama Islam Negeri Metro \\ andriasmuthia@gmail.com
}

\begin{abstract}
This study aims to determine the effect tawakkal towards students' emotional stability. Data collection techniques were questionnaires and documentation. The results of the questionnaire were analyzed using product moment correlation analysis techniques using SPSS 16. From the results of hypothesis testing obtained rcount $=0.676>$ rtable $=2.29$ and a significance value of 0,000 <0.05, which means that $\mathrm{HO}$ is rejected and Hi is accepted so that the results of this study are there is an influence of tawakal towards student emotional stability. The higher of tawakal, the higher the emotional stability of the students. Conversely the lower of tawakal, the lower the emotional stability of students. It is important to have a tawakal because through the tawakal a person can fully surrender himself to Allah. High submission to God gives rise to tranquility and peace of mind. Tranquility and peace of mind make one's emotions stable.
\end{abstract}

\section{Keywords: Tawakal, Emotion}

\begin{abstract}
Abstrak
Penelitian ini bertujuan untuk mengetahui pengaruh sikap tawakkal terhadap kestabilan emosi siswa. Metode pengumpul data dalam penelitian ini adalah angket dan dokumentasi. Hasil angket dianalisa dengan teknik analisa korelasi product moment dengan menggunakan SPSS 16. Dari hasil uji hipotesis diperoleh $\mathrm{r}_{\text {hitung }}=0,676>\mathrm{r}_{\text {tabel }}=2,29$ dan nilai signifikansi $0,000<0,05$ yang berarti $\mathrm{H}_{0}$ ditolak dan $\mathrm{H}_{\mathrm{i}}$ diterima sehingga hasil penelitian ini adalah ada pengaruh antara sikap tawakal terhadap kestabilan emosi siswa. Semakin tinggi sikap tawakal maka semakin tinggi kestabilan emosi siswa. Sebaliknya semakin rendah sikap tawakal, maka semakin rendah kestabilan emosi siswa. Sikap tawakal penting dimiliki karena melalui sikap tawakal seseorang bisa sepenuhnya memasrahkan diri kepada Allah. Kepasrahan yang tinggi kepada Allah memunculkan ketenangan dan ketenteraman hati. Ketenangan dan ketenteraman hati menjadikan emosi seseorang stabil.
\end{abstract}

Kata Kunci: Tawakal, Emosi 


\section{A. PENDAHULUAN}

Modernisasi membawa pada kemajuan ilmu pengetahuan dan teknologi. Namun modernisasi telah menyebabkan perubahan nilai-nilai kehidupan. Nilai-nilai moral, etika, agama dan tradisi lama ditinggalkan karena dianggap usang ${ }^{1}$. Perubahan nilai ini dapat dilihat dari pola hidup masyarakat yang mengarah pada sisi kehidupan yang materialistis. Pola hidup yang semula lebih cenderung pada sisi sosial religius berubah ke arah yang bersifat individualis yang cenderung bersifat sekuler. Pola hidup sederhana berubah ke pola hidup mewah dan konsumtif, hubungan kekeluargaan yang semula erat dan kuat cenderung semakin longgar, rapuh, dan kurang adanya makna kebersamaan. Nilai-nilai agama dan tradisional masyarakat cenderung berubah menjadi masyarakat modern bercorak sekuler dan serba boleh.

Sifat, kebiasaan, karakter dan kepribadian manusia sekarang lebih banyak dipengaruhi atau dibentuk oleh lingkungan sosialnya. Hal ini banyak dipengaruhi oleh pola hidup bergaya modern yang mengakibatkan orang tidak punya pegangan hidup dan selalu merasa ketakutan, bahkan kehidupan dibayang-bayangi keputus-asaan, tidak punya arah dan tanpa adanya tujuan yang pasti. Bahkan adanya perubahanperubahan sosial yang serba cepat berdampak pada ketidakstabilan emosi dan kurang adanya kesepakatan antar

1 Dadang Hawari, Al-Qur'an : Ilmu Kedokteran Jiwa dan Kesehatan Jiwa, (Jakarta : Dana Bhakti Prima Yasa, 1996), hal. 15 anggota masyarakat mengenai pola hidup sehari-hari.

Banyak kasus di masyarakat akibat orang tidak mampu menghadapi permasalahan kemudian berdampak pada tekanan emosi yang negatif seperti sedih, marah, kecewa, putus asa, mangkel, jenuh dan lain-lain. Seperti kasus siswa yang melakukan bunuh diri akibat tidak lulus ujian, maraknya tawuran siswa diberbagai sekolah akibat saling mengejek, siswa yang suka membolos, seorang suami memukul istri hingga tewas akibat rasa marah dan tersinggung, dan banyak kasus lainnya yang sering diberitakan di media massa maupun media elektronik.

Untuk menghadapi permasalahan dari modernisasi agar tidak berdampak negatif, perlu adanya solusi yang terbaik. Solusi yang mengandalkan rasio saja tidak akan menjadi jalan keluar yang baik, karena akan membuat modernisasi lepas kendali. Oleh karena itu sebagai jalan keluar terbaik adalah kembali pada dimensi spiritual (melaksanakan ajaran agama). Dengan kembali pada ajaran agama dalam kehidupan sehari-hari dapat membentengi diri dari kejatuhan atau gangguan jiwa dan dapat pula mengembalikan kesehatan jiwa bagi orang yang gelisah.

Dalam pandangan Islam selain berusaha (ikhtiar) untuk menyelesaikan masalah, ada satu ajaran yang dapat membuat seseorang merasa tenang yaitu sikap tawakal (memasrahkan diri kepada Allah atas segala permasalahan yang terjadi). Tawakal merupakan amalan dan ubudiyah (penghambaan) 
hati dengan menyandarkan segala sesuatu hanya kepada Allah, tsiqoh kepada-Nya, berlindung hanya kepadaNya dan ridho atas sesuatu yang menimpa dirinya berdasarkan keyakinan bahwa Allah akan memberikan segala "kecukupan" bagi dirinya dengan tetap melaksanakan "sebab-sebab" (faktor-faktor yang mengarahkannya pada sesuatu yang dicarinya) serta usaha keras untuk dapat memperolehnya ${ }^{2}$.

Tawakal bagi seorang muslim merupakan kebutuhan pokok. Dengan adanya sikap tawakal orang akan tenang dan memiliki kestabilan emosi ketika menghadapi sebuah permasalahan yang sering membuat manusia berpikir keras, menimbulkan emosi dan melelahkan jiwa dan raga. Seseorang dikatakan memiliki stabilitas emosi ketika ia sanggup untuk menghadapi tekanan hidup baik ringan maupun berat dengan kondisi emosi tetap baik (mampu mengatur emosi) ${ }^{3}$.

Berdasarkan observasi dan interview dengan guru Madrasah Aliyah Negeri (MAN) 1 Metro, peneliti menemukan dampak tidak stabilnya emosi pada siswa, seperti bolos sekolah, suka mengejek teman, mudah mengalami kecemasan, mudah putus asa, emosi yang cenderung meledakledak dan melanggar ketertiban. Ketidakstabilan emosi siswa ini dimungkinkan karena siswa belum sepenuhnya memasrahkan diri kepada

${ }^{2}$ Al-Jauzi, Al-Ruh fi Kalam ala Arwah Al-Amwat wa Al-Ahya' bidalail min Al-Kitab wa Al-Sunnah, 1975, hal. 254

${ }^{3}$ http://repository.upi.edu/operator/uploa d/s_ppb_0608965_chapter3.pdf
Allah dan ridho terhadap semua hal yang terjadi. Dengan kata lain siswa belum memiliki sikap tawakal. Hal ini bisa saja dipengaruhi karena rendahnya motivasi, ataupun karena lingkungan pergaulan maupun lingkungan keluarga.

Dengan adanya keimanan yang teguh dan kuat serta berkeyakinan bahwa Allah memberikan jaminan tentu akan menimbulkan rasa optimis dan tenteram pada diri seseorang. Keyakinan seperti inilah yang sangat diperlukan di zaman modernisasi ini. Oleh karena itu perlu adanya penelitian tentang tawakal dan emosi serta mengkaji pengaruh dari sikap tawakal terhadap kestabilan emosi dengan rumusan masalah yaitu: Apakah ada pengaruh antara sikap tawakal terhadap kestabilan emosi siswa?

\section{B. KERANGKA TEORI}

\section{Tawakal}

Tawakkal adalah menyandarkan kepada Allah swt tatkala menghadapi suatu kepentingan, bersandar kepadaNya dalam waktu kesukaran, teguh hati tatkala ditimpa bencana disertai jiwa yang tenang dan hati yang tenteram. Sedangkan Abu Zakaria Ansari mengatakan tawakal merupakan "keteguhan hati dalam menyerahkan urusan kepada orang lain"4. Sifat yang demikian itu terjadi sesudah timbul rasa percaya kepada orang yang diserahi urusan tadi. Artinya, ia betulbetul mempunyai sifat amanah

4 http://www.tawakal.or.id/arti-maknatawakal/; M. Yatimin Abdullah, Studi Akhlak Dalam Perspektif Al-Qur'an, (Jakarta : Amzah, 2007), hal. 53 
(terpercaya) terhadap apa yang diamanatkan dan ia dapat memberikan rasa aman terhadap orang yang memberikan amanat tersebut.

Tawakkal adalah suatu sikap mental seorang yang merupakan hasil dari keyakinannya yang bulat kepada Allah, karena di dalam tauhid ia diajari agar meyakini bahwa hanya Allah yang menciptakan segala-galanya, pengetahuan-Nya Maha Luas, Dia yang menguasai dan mengatur alam semesta ini. Keyakinan inilah yang mendorongnya untuk menyerahkan segala persoalannya kepada Allah. Hatinya tenang dan tenteram serta tidak ada rasa curiga, karena Allah Maha Tahu dan Maha Bijaksana.

Seseorang yang bertawakal adalah seseorang yang menyerahkan, mempercayakan dan mewakilkan segala urusannya hanya kepada Allah swt. Karena mengandung makna “mempercayakan diri”, maka tawakal merupakan implikasi langsung iman. Sebab iman tidak saja berarti "percaya akan adanya" Tuhan, tapi lebih bermakna "mempercayai" atau "menaruh kepercayaan" kepada Tuhan satu-satu-Nya tanpa sekutu, yaitu Allah, Tuhan Yang Maha Esa. Maka tidak ada tawakal tanpa iman dan tidak ada iman tanpa tawakal ("Dan kepada Allah hendaknya kamu sekalian bertawakal, kalau benar kamu adalah orang-orang yang beriman (QS. AlMaidah 5 : 23), bahkan tidak ada iman, tidak pula ada sikap pasrah kepada Allah (Islam), begitu pula sebaliknya ("Kalau kamu sekalian benar-benar beriman kepada Allah, maka beertawakallah kepada-Nya, jika memang kamu orang-orang yang pasrah (muslim) (QS. Yunus, $10: 84$ ) 5.

Menurut Imam Ahmad bin Hanbal tawakal merupakan aktivitas hati, artinya tawakal itu merupakan perbuatan yang dilakukan hati, bukan sesuatu yang diucapkan oleh lisan, bukan pula sesuatu yang dilakukan oleh anggota tubuh. Tawakal juga bukan merupakan sebuah keilmuan dan pengetahuan ${ }^{6}$. Sedangkan menurut Ibnu Qoyim Al-Jauzi tawakal merupakan amalan dan ubudiyah (penghambaan) hati dengan menyandarkan segala sesuatu hanya kepada Allah, tsiqoh kepada-Nya, berlindung hanya kepadaNya dan ridho atas sesuatu yang menimpa dirinya berdasarkan keyakinan bahwa Allah akan memberikan segala "kecukupan" bagi dirinya dengan tetap melaksanakan "sebab-sebab" (faktor-faktor yang mengarahkannya pada sesuatu yang dicarinya) serta usaha keras untuk dapat memperolehnya ${ }^{7}$.

Dengan demikian tawakal artinya berpasrah diri kepada Allah setelah melakukan ikhtiar terlebih dahulu ${ }^{8}$. Ini menunjukkan bahwa tawakal bukan

${ }^{5}$ Nurcholish Madjid, Islam Doktrin dan Peradaban, (Jakarta : Yayasan Wakaf Paramadina, 1995), Hal. 46

${ }^{6}$ Al-Jauzi, Tahdzib Madarijis Salikin,tt, hal. 337

${ }^{7}$ Al-Jauzi, Al-Ruh fi Kalam ala Arwah Al-Amwat wa Al-Ahya' bidalail min Al-Kitab wa Al-Sunnah, 1975, hal. 254

${ }^{8}$ Didiek Ahmad Supadie, Pengantar Studi Islam, (Jakarta : Rajawali Press, 2011) hal. 225; lihat juga Sa'id Hawwa, Al Islam Jilid 1, terjemahan Abu Ridho, Aunur Rafiq Shaleh Tamhid, (Jakarta : Al-I'tishom, 2001), hal. 125; Yunahar Ilyas, Kuliah Aqidah Islam, (Yogyakarta : LPPI Universitas Muhammadiyah Yogyakarta, 1993), hal. 39 
berarti meninggalkan usaha. Bahkan Allah menyuruh kita untuk berusaha (bekerja), namun kita dilarang menggantungkanhidup kita pada usaha (pekerjaan) tersebut.

Berbeda dengan kesan kebanyakan orang, tawakal bukanlah sikap pasif dan bersemangat melarikan diri dari kenyataan (eskapis). Tawakal adalah sikap aktif, dan tumbuh hanya dari pribadi yang memahami hidup dengan tepat serta menerima kenyataan hidup dengan tepat pula. Sebab pangkal tawakal adalah kesadaran diri bahwa perjalanan pengalaman manusia secara keseluruhan dalam sejarah - untuk tidak mengatakan perjalanan pengalaman perorangan dalam kehidupan diri pribadi - tidak akan cukup untuk menemukan hakikat hidup. Sebagian besar dari hakikat itu tetap merupakan rahasia Ilahi yang tidak ada jalan bagi makhluk untuk menguasainya 9 .

${ }^{9}$ Di kalangan orang kebanyakan (awan, umum), tawakal memang sering diartikan sebagai sikap pasif, menunggu apa saja yang bakal terjadi pada diri seseorang atau lainnya, tanpa usaha aktif atau ikhtiar meraih atau menolak. Sesungguhnya pengertian tawakal seperti ini meyalahi ajaran agama seperti dianut oleh kebanyakan ulama. Kyai H. Muhammad Shalih ibn 'Umar samarani (Kyai Shaleh Darat) menjelaskan hal ini (dalam bahasa Jawa, huruf pehgo) demikian : Anapon mungguh kersane jumhur al-muhaqqiqin iku setuhune tawakal iku ora dadi nafekaken kasab. Maka ana wong iku kasab sartane tawakal, lan orak rusak tawakal kalawan sabab kasab, mengkono ora. Kerana maknane tawakal iku ngandel ing Allah Subhanahu wa Ta'alanlan gendolan marang Allah, senajan sartane nglakoni asbab al kasab. Alhasil ing dalem zaman iki utama kasab balik wajib kasab, kerana ora sampurna iman al-'awamm lan Islame awan anging kalawan mal. Riwayat sangking Sayyidina Anas r.a. qala (Rasulullah) s.a.w., "Ni'ma alwan 'ala taqwa llah al-mal”, (Ana dene bagus-
Tawakal merupakan gabungan dari berbagai unsur yang menjadi satu. Tanpa adanya unsur-unsur tersebut tawakal tidak dapat direalisasikan. Unsur-unsur dari tawakal tersebut adalah:

1. Ma'rifah atau mengenal Tuhan beserta sifat-sifat-Nya

2. Memiliki keyakinan akan keharusan melakukan usaha (Ikhtiar)

3. Ketetapan hati dalam mentauhidkan (mengesakan)

4. Menyandarkan atau menggantungkan hati hanya kepada Allah saja

baguse perkara ingkang mitulungi ingatase taqwa 'lla iku arta". Wa qala (Rasulullah )s.a.w., "Inna al-faqah li ashhabi sa'adah wa inna al-ghina li al-mu'min fi akhir zaman sa'adah". (Ana dene fakire sahabat ingsun iku begja, lan setuhune sugih keduwe wong mukmin besuk ing dalem akhir al-zaman iku sa'adah). Rawahu Jabir. Wa qala (Rasulullah)s.aa.w., "Izz al-mu'min ghina uhu 'an al-nas." (Ana dene mulyane wong mukmin iku sugihe sangking manusa).

(Adapun menurut pendapat sebagian besar para ahli, tawakal tidak berarti menghilangkan kerja (kasab). Ada orang bekerja (aktif) dan tetap tawakal, dan tawakalnya itu tidak rusak karena kerja. Sebab makna tawakal ialah percaya kepada Allah s.w.t. dan berpegang kepada-Nya, meskipun disertai tindakan menempuh cara-cara kerja. Kesimpulannya, pada zaman sekarang lebih baik kerja, malah wajib, karena iman orang umum dan ke-Islaman mereka tidak sempurna kecuali dengan adanya harta. Hadis riwayat Anas menceritakan bahwa Rasulullah s.a.w. bersabda, "Sebaik-baik penopang bagi taqwa kepada Allah ialah harta". Dan sabda beliau lagi, "Kemiskinan bagi sahabat-sahabatku adalah kebahagiaan, dan kekayaan bagi orangorang beriman di akhir zaman adalah kebahagian". (Diriwayatkan oleh Jabir). Beliau (Nabi s.a.w.) juga bersabda, "Kemuliaan seorang mukmin ialah kemandiriannya dari orang lain. Nurcholish Madjid, Islam Doktrin dan Peradaban, h. 46 
5. Berbaik sangka (husnudzan) kepada Allah

6. Berpasrah Diri kepada Allah,

7. Ridla terhadap apa yang terjadi.

Tawakal sangat dianjurkan oleh

Allah swt. Hal ini karena tawakal memiliki beberapa manfaat. Di antara manfaat tawakal itu adalah ${ }^{10}$ :

a. Tawakal memberi Ketenangan

Jiwa dan Ketentraman Hati

Sebagaimana diketahui bahwa buah tawakal yang paling mulia adalah bahwa ketika seorang hamba menyerahkan kepemimpinannya (kendalinya) kepada Sang Penciptanya yang memberinya rezeki dan sekaligus Tuhannya, ia juga ridha dengan apa yang Allah berikan padanya, dan ia menyerahkan semua urusannya kepada-Nya serta percaya dengan apa yang telah Allah janjikan, maka tidak diragukan lagi bahwa orang itu akan mendapatkan ketenangan di dalam hatinya dan kenyamanan dalam jiwanya yang tidak bisa diungkapkan oleh kata-kata akan tetapi dapat dirasakan oleh orang yang telah menemukan buah tawakal itu, karena buah tawakal adalah sesuatu yang amat melapangkan dada dan tidak ada yang bisa melapangkan hati selain sikap tawakal - tentunya setelah beriman yang berupa kepercayaan seseorang kepada Allah, mengharapkan pada-Nya dan berbaik sangka pada-Nya.

Jika seorang hamba bertawakal kepada Allah dengan sebenar-benarnya tawakal maka Allah akan mengangkat

10 Abdullah bin Umar Ad-Dumaji, Rahasia Tawakal Dan Sebab Akibat, Terjemahan Kamaluddin Sa'diatuloharamaini, (Jakarta : Pustaka Azzam, 2000), hal. 65 darinya kesedihannya dan membuat ia nyaman dari sesuatu yang membuatnya gelisah, lalu Allah menurunkan pada diri orang itu ketenangan, diri orang itu akan diliputi dengan ketenangan yang syar'i dan alami tanpa ketakutan dan kekhawatiran.

b. Keyakinan Allah akan mencukupi semua urusan orang yang bertawakal kepada-Nya

Hal ini berdasarkan dari firman Allah yang berbunyi: "Dan barangsiapa yang bertawakkal kepada Allah niscaya Allah akan, mencukupkan (keperluan)nya. "(Ath-Thalaq:3). "Makna mencukupkan"menurut ArRobi' bin Khutsaim adalah " Dari segala sesuatu, yang menyempitkan (menyusahkan) manusia".

Allah adalah yang mencukupi orang yang bertawakal kepada-Nya dan yang menyandarkan diri kepadaNya, yaitu Dia yang memberi ketenangan dari ketakutan orang yang takut, Dia adalah sebaik-baik pelindung dan sebaik-baik penolong dan barang siapa yang berlindung pada-Nya dan meminta pertolongan dari-Nya dan bertawakal kepada-Nya, maka Allah akan melindunginya, menjaganya, dan barang siapa yang takut kepada Allah, maka Allah akan membuatnya nyaman dan tenang dari sesuatu yang ditakuti dan dikhawatirkannya, dan Allah akan memberi kepadanya segala macam kebutuhan yang bermanfaat. Ini adalah ganjaran yang paling besar karena Allah SWT akan menjadikan diri-Nya sendiri sebagai yang memenuhi segala kebutuhan orang yang bertawakal kepadaNya. 
c. Tawakal dapat menghasilkan kemantapan, keberanian dan kekuatan hati dan perlawanan terhadap musuh

Di antara buah tawakal adalah mendatangkan keberanian, kekuatan hati dan perlawanan terhadap musuh walaupun musuhnya itu kuat dan besar, kekuatan yang sebenar-benarnya kekuatan yang terdapat dalam sikap tawakal.

Telah diriwayatkan dari Ibnu Abbas di Nabari SAW bersabda: barang siapa yang ingin menjadi manusia terkuat maka hendaknya ia bertawakal kepada Allah, dan barang siapa yang ingin menjadi manusia terkaya hendaklah ia yakin dan percaya dengan apa yang terdapat di kedua tangannya, dan barang siapa yang ingin menjadi manusia termulia maka hendaklah ia bertaqwa kepada Allah.

Oleh karena itu dalam Al-Qur'an disebutkan bahwa tawakal disertakan dengan perbuatan untuk melawan musuh, tidak perlu memperdulikan mereka sebagaimana Firman Allah "Dan mereka (orang-orang,munafik) mengatakan: "(Kewajiban kami hanyalah) ta'at ". Tetapi apabila mereka telah pergi dari sisimu, sebahagian dari mereka mengatur siasat di malam hari (mengambil keputusan) lain dari yang telah mereka katakan tadi. Allah menulis siasat yang mereka atur di malam hari itu, maka berpalinglah kamu dari mereka dan tawakkallah kepadaAllah. cukuplah Allah menjadi Pelindung. " (An-Nisa': 81)

d. Tawakal melindungi diri dari penyakit Ujub dan Takabur
Sesungguhnya penyakit yang paling besar; serta mematikan yang menimpa hati manusia, serta dapat menjadikan amalan-amalan sia-sia, juga merusak seluruh perbuatan manusia serta melahirkan kekerasan dan kekejian adalah; Riya dan Ujub. Riya adalah bagian dari perbuatan syirik menyekutukan Allah, sementara ujub adalah bagian dari perbuatan syirik terhadap, diri, sendiri, kedua sikap ini menyatu pada diri orang yang takabur.

Oleh karena itulah Ibnul Qayyim berkata: sesungguhnya hati manusia itu dihadapi oleh dua macam penyakit yang amat besar jika orang itu tidak menyadari adanya kedua penyakit itu akan melemparkan dirinya kedalam kehancuran dan itu adalah pasti, kedua penyakit itu adalah riya dan takabur, maka obat dari pada riya adalah: (hanya kepadaMu kami menyembah) dan obat dari penyakit takabur adalah: (hanya kepada-Mu kami memohon pertolongan).

Orang yang tawakal apabila dia sudah melaksanakan ikhitiar dan mampu menyelesaikan masalah, dia akan bersyukur kepada Allah dan hilang dari dirinya sikap riya dan takabur. Karena ia sadar bahwa apa yang telah diperolehnya bukan sematamata hasil ikhtiarnya melainkan ada Allah yang telah mengabulkan ikhtiarnya.

\section{Emosi}

Manusia adalah makhluk yang memiliki rasa dan emosi. Hidup manusia diwarnai dengan emosi dan berbagai macam perasaan. Manusia sulit menikmati hidup secara optimal 
tanpa memiliki emosi. Manusia bukanlah manusia, jika tanpa emosi. Kita memiliki emosi dan rasa, karena emosi dan rasa menjadi bagian yang tidak terpisahkan dalam kehidupan kita manusia.

Ahli psikologi memandang manusia adalah makhluk yang secara alami memiliki emosi. Menurut teori James-Lange dalam Wirawan emosi adalah hasil persepsi seseorang terhadap perubahan-perubahan yang terjadi pada tubuh sebagai respon terhadap rangsangan-rangsangan yang datang dari luar ${ }^{11}$. Oleh karenanya emosi adalah keadaan jiwa yang menampakkan diri dengan sesuatu perubahan yang jelas pada tubuh. Emosi setiap orang mencerminkan keadaan jiwanya, yang akan tampak secara nyata pada perubahan jasmaninya. Sebagai contoh ketika seseorang diliputi emosi marah, wajahnya memerah, napasnya menjadi sesak, otot-otot tangannya akan menegang,dan energi tubuhnya memuncak $^{12}$. Jadi adanya perrubahanperubahan kejasmaniahan sebagai rangkaian dari emosi yang dialami oleh individu yang bersangkutan.

Emosi merupakan keadaan yang ditimbulkan oleh situasi tertentu. Emosi cenderung terjadi dalam kaitannya dengan perilaku yang mengarah (approach) atau menyingkir

11 Sarlito Wirawan Sarwono, Pengantar Umum Psikologi, (Jakarta : Bulan Bintang, 1976), hal. 52

12 Triantoro Safaria dan Nofrans Eka Saputra, Manajemen Emosi Sebuah panduan Cerdas Bagaimana Mengelola Emosi Positif Dalam Hidup Anda, (Jakarta : Bumi Aksara, 2009), hal. 11 (avoidance) terhadap sesuatu. Perilaku tersebut pada umumnya disertai adanya ekspresi kejasmanian sehingga orang lain dapat mengetahui bahwa seseorang sedang mengalami emosi. Misalnya kalau orang mengalami ketakutan, mukanya menjadi pucat, jantungnya berdebar-debar ${ }^{13}$.

Perubahan-perubahan tubuh saat terjadi emosi - terutama pada emosi yang kuat- antara lain ${ }^{14}$ :

1. Reaksi elektris pada kulit : meningkat bila terpesona

2. Perdaran darah : bertambah cepat bila marah

3. Denyut jantung : bertambah cepat bila terkejut

4. Pernapasan : bernapas panjang bila kecewa

5. Pupil mata : membesar bila sakit atau marah

6. Liur : mengering kalau takut atau tegang

7. Buluroma : berdiri kalau takut

8. Pencernaan : mencret-mencret kalau tegang

9. Otot : ketegangan dan ketakutan menyebabkan otot menegang aatau bergetar (tremor)

10. Komposisi darah : komposisi darah akan ikut berubah dalam keadaan emosionil kerena kelenjar-kelenjar lebih aktif

Dengan demikian dapat diketahui bahwa kondisi emosi seseorang dapat berpengaruh pada kondisi fisik, sehingga akan muncul perubahan-

13 Bimo Walgito, Pengantar Psikologi Umum, (Yogyakarta : Andi Offset, 1990), hal. 146

14 Sarlito Wirawan Sarwono, Pengantar Umum Psikologi, hal 53 
perubahan jasmani. Oleh karena itu emosi yang merupakan cerminan keadaan jiwa akan tampak nyata pada perubahan jasmaninya.

Pada dasarnya emosi manusia bisa dibagi menjadi dua kategori umum jika dilihat dari dampak yang ditimbulkannya ${ }^{15}$. Kategori pertama adalah emosi positif atau biasa disebut afek positif. Emosi positif memberikan dampak yang menyenangkan dan menenangkan. Macam dari emosi positif ini seperti tenang, santai, rileks, gembira, lucu, haru dan senang. Ketika kita merasakan emosi positif ini, kita pun akan merasakan keadaan psikologis yang positif.

Kategori kedua adalah emosi negatif atau afek negatif. Ketika kita merasakan emosi negatif ini maka dampak yang kita rasakan adalah negatif, tidak menyenangkan dan menyusahkan. Macam dari emosi negatif diantaranya sedih, kecewa, putus asa, depresi, tidak berdaya, frustasi, marah, dendam dan masih banyak lagi.

Biasanya kita menghindari dan berusaha menghilangkan emosi negatif ini. Adakalanya kita mampu mengendalikannya, tetapi adakalanya kita gagal melakukannya. Ketika kita gagal mengendalikan atau menyeimbangkan emosi negatif ini maka ketika itu keadaan suasana hati kita menjadi buruk.

Kesejahteraan psikologis dan kebahagiaan seseorang lebih ditentukan

15 Triantoro Safarian dan Nofrans Eka Saputra, Manajemen Emosi Sebuah panduan Cerdas Bagaimana Mengelola Emosi Positif Dalam Hidup Anda, hal 13. oleh perubahan atau pengalaman emosional yang sering dialaminya. Hal ini disebut sebagai afek. Jika individu lebih banyak merasakan dan mengalami afek negatif seperti marah, benci, dendam dan kecewa maka individu akan diliputi oleh suasana psikologis yang tidak nyaman dan tidak menyenangkan. Akibatnya, individu akan terasa sulit merasakan kepuasan hidup dan kebahagiaan.

Pemahaman, penerimaan diri akan suasana emosi, mengetahui secara jelas makna dari perasaan, mampu mengungkapkan perasaan secara konstruktif merupakan hal-hal yang mendorong tercapainya kesejahteraan psikologis, kebahagiaan, dan kesehatan jiwa individu. Orang yang mampu memahami emosi apa yang sedang mereka alami dan rasakan, akan lebih mampu mengelola emosinya secara positif. Sebaliknya, orang yang kesulitan memahami emosi apa yang sedang bergejolak dalam perasaannya, menjadi rentan dan terpenjara oleh emosinya sendiri. Mereka menjadi bingung dan bimbang akan makna dari suasana emosi yang sedang mereka rasakan.

Menurut pandangan teori kognitif, emosi lebih banyak ditentukan oleh hasil interpretasi kita terhadap sebuah peristiwa. Kita bisa memandang dan menginterpretasikan sebuah peristiwa dalam persepsi atau penilai negatif, tidak menyenangkan, menyengsarakan, menjengkelkan, mengecewakan, atau sebaliknya dalam persepsi yang lebih positif seperti sebuah kewajaran, hal yang indah, sesuatu yang mengharukan, atau 
membahagiakan. Interpretasi yang kita buat atas sebuah peristiwa mengkondisikan dan membentuk perubahan fisiologi kita secara internal. Ketika kita menilai sebuah peristiwa secara lebih positif maka perubahan fisiologis kita pun menjadi lebih positif.

\section{Tawakal dan Kestabilan Emosi}

Manusia adalah makhluk spiritual, karena itu tentu saja manusia tidak bisa melepaskan diri dari kebermaknaan spritual. Apabila melihat sekitar kita, seringkali orangorang yang meninggalkan dunia spritualnya menjadi mudah terrombang ambing dalam kebimbangan, keraguan dan kehilangan makna dalam hidupnya. Mereka kemudian terjebak dalam dunia yang menekankan nilai-nilai materialisme sehingga mudah sekali mengalami kehampaan hidup ketika nilai-nilai materialisme tidak lagi bisa memberikan makna dalam hidupnya.

Setiap manusia memiliki kebutuhan dasar spiritual yang harus dipenuhinya. Pemenuhan terhadap kebutuhan spiritual akan memunculkan perasaan aman, damai dan tenteram, serta membebaskan manusia dari perasaan cemas, hampa dan takut. Tak salah lagi apabila ada manusia untuk menguatkan resiliensi dirinya dari sebuah ancaman atau bahaya dengan memperkaya kebermaknaan spiritual dalam kehidupannya ${ }^{16}$.

Kecerdasan spiritual akan membawa individu di dalam spiritualitas yang sehat, yaitu spiritual

16 Ibid, hal. 226 yang memberikan penghargaan terhadap kebebasan personal, otonomi, harga diri, termasuk juga di dalamnya mengajak individu untuk menjalankan tanggungjawab sosialnya. Spiritual yang sehat tidak menafikan kemanusiaan manusia, tidak mengabaikan hati nurani, namun justru senantiasa mengajak individu pada kasih sayang, cinta dan perdamaian. Spiritualitas yang sehat merupakan pengkristalan dari kebijaksanaan yang senantiasa menghargai perbedaan, kreativitas dan membebaskan manusia dari kezaliman. Spiritualitas yang sehat tidak menjadi tameng atau dogma untuk menghancurkan orang lain, berbuat kerusakan di muka bumi, atau digunakan sebagai alat untuk kepentingan diri sendiri dengan mengabaikan hak-hak orang lain.

Kebermaknaan spiritual telah banyak ditelaah oleh para ahli di berbagai belahan dunia, dan beberapa penelitiannya menegaskan bahwa ada hubungan yang positif antara kebermaknaan spiritual dengan kesehatan mental seseorang. Kesehatan mental sendiri mencakup suatu kondisi yang memungkinkan terjadinya perkembangan fisik, intelektual, dan emosional yang optimal serta mencakup keadaan yang harmonis dari semua segi kehidupan individu dalam hubungannya dengan orang lain.

Penelitian Lidenthal, dkk. diperoleh kesimpulan bahwa kelompok masyarakat yang religius jauh dari stress dibandingkan dengan kelompok masyarakat yang kurang religius. Comstock dan Partrige menyimpulkan bahwa komitmen agama pada individu 
menurunkan angka kematian bunuh diri. Mereka yang jarang mengamalkan ajaran agamanya ternyata mempunyai resiko empat kali untuk bunuh diri dibandingkan dengan mereka yang rajin dalam menjalankan komitmen agamanya. Ahli lainnya, Link menemukan bahwa penelitiannya bahwa individu yang aktif beribadah ke tempat peribadatan ternyata memiliki kepribadian yang lebih sehat dibandingkan mereka yang kurang aktif beribadah ${ }^{17}$.

Dalam pandangan Islam selain berusaha (ikhtiar) untuk menyelesaikan masalah, ada satu ajaran yang dapat membuat seseorang merasa tenang yaitu sikap tawakal (memasrahkan diri kepada Allah atas segala permasalahan yang terjadi). Ketika seseorang telah memiliki sikap tawakal yang diindikasikan dengan adanya ma'rifah atau mengenal Tuhan beserta sifatsifat-Nya, adanya ikhtiar, ketetapan hati dalam mentauhidkan (mengesakan), menyandarkan atau menggantungkan hati hanya kepada Allah saja, berbaik sangka kepada Allah, sikap pasrah diri kepada Allah, ridla terhadap apa yang terjadi, maka dapat memiliki kestabilan emosi ketika menghadapi sebuah permasalahan.

Kestabilan emosi tersebut diwujudkan dengan adanya kemampuan seseorang untuk mengatur perasaan-perasaan tertentu yang sedang dirasakan pada situasi tertentu yang diwujudkan pada menahan diri atau mengendalikan emosi, mengungkapkan emosi secara tepat, menyelesaikan

\footnotetext{
${ }^{17}$ Ibid, hal 228
}

masalah, mampu memotivasi diri sendiri, dan mampu untuk dapat menyelesaikan perasaan dengan lingkungan sekitar.

Adapun sub stabilitas emosi tersebut adalah :

a. Pengendalian emosi yaitu kemampuan untuk menahan perasaan dalam bentuk kemampuan menenangkan diri, mengatur emosi, mengatasi dorongan emosi dalam bentuk penyaluran emosi dengan melakukan kegiatan, mempertahankan sikap positif yang realistis terutama dalam menghadapi masa-masa sulit dan mampu menahan atau menunda keinginan untuk bertindak.

b. Pengungkapan emosi yaitu kemampuan untuk mengekspresikan perasaan dalam bentuk sedih, marah, cemas, bahagia dan cinta serta kemampuan menyampaikan pikiran secara jelas.

c. Penyelesaian masalah yaitu kemampuan bertindak atau menerapkan pemecahan yang jitu dan tepat.

d. Kemampuan memotivasi diri sendiri yang diwujudkan dalam bentuk kemampuan menyukai diri sendiri dan kemampuan untuk dapat selalu optimis atau tidak mudah putus asa.

e. Kesesuaian antara perasaan dengan lingkungan yang diwujudkan dalam bentuk kemampuan menjadi anggota masyarakat yang dapat bekerjasama, kemampuan menjadi anggota masyarakat yang mampu 
memahami perasaan orang lain dari sudut pandang yang berbeda dan kemampuan menyesuaikan diri dengan keadaan yang berubahubah.

Berdasarkan sub stabilitas emosi di atas dapat disimpulkan bahwa indikator stabilitas emosi adalah :

a. Mampu menenangkan diri

b. Mampu mengatur emosi

c. Mampu mengatasi dorongan emosi dalam bentuk penyaluran emosi dengan melakukan kegiatan

d. Mampu mempertahankan sikap positif yang realistis terutama dalam menghadapi masa-masa sulit

e. Mampu menahan atau menunda keinginan untuk bertindak

f. Mengungkapkan emosi secara tepat

g. Mampu bertindak atau menerapkan pemecahan masalah yang jitu dan tepat

h. Mampu menyukai diri sendiri

i. Mampu untuk selalu optimis atau tidak mudah putus asa

j. Mampu menjadi anggota masyarakat yang dapat bekerjasama

k. Mampu menjadi anggota masyarakat yang mampu memahami perasaan orang lain dari sudut pandang yang berbeda

1. Mampu beradaptasi dengan keadaan yang berubah-ubah.

Dengan demikian orang yang memiliki stabilitas emosi dia akan selalu percaya diri, optimis, tenang, mampu menyalurkan emosi secara tepat, serta mampu beradaptasi dengan lingkungannya ketika ia menghadapi berbagai masalah di era modernisasi ini yang penuh dengan harapan dan tantangan. Sikap-sikap ini muncul karena ia bertawakal kepada Allah. Ketika orang bertawakal maka dengan keimanan yang teguh dan kuat serta berkeyakinan bahwa Allah memberikan jaminan tentu akan menimbulkan rasa optimis, berani, dan tenteram. Sehingga dia akan memunculkan sikap yang baik dan mampu menjadi anggota masyarakat yang baik.

Dari uraian-uraian di atas dapat disimpulkan bahwa tawakal sangat penting dimiliki oleh manusia. Karena dengan sikap tawakal manusia akan bertahan menghadapi tekanan modernisasi yang penuh dengan tantangan dan persaingan yang sering membuat manusia mengalami permasalahan hidup dan emosi. Tawakal bukanlah pasrah tanpa ikhtiar, akan tetapi tawakal adalah kepasrahan yang didahului dengan kerja.

Tawakal sangat dianjurkan oleh Allah. Banyak ayat-ayat Al-Qur'an yang menyerukan manusia. Bahkan kata tawakal sering digandengkan dengan kata iman. Tawakal ini sangat dianjurkan terutama dalam menyelesaikan permasalahan hidup yang akan membawa pada kestabilan emosi karena tawakal memberi ketenangan jiwa dan ketentraman hati, keyakinan Allah akan mencukupi semua urusan orang yang bertawakal kepada-nya, dapat menghasilkan kemantapan, keberanian dan kekuatan hati dan perlawanan terhadap musuh dan tawakal dapat melindungi diri dari penyakit ujub dan takabur. 
Orang yang memiliki stabilitas emosi ia akan mampu untuk mengatur perasaan-perasaan tertentu yang sedang dirasakan pada situasi tertentu yang diwujudkan pada menahan diri atau mengendalikan emosi, mengungkapkan emosi secara tepat, menyelesaikan masalah, mampu memotivasi diri sendiri, dan mampu untuk dapat menyelesaikan perasaan dengan lingkungan sekitar

\section{HASIL PENELITIAN DAN PEMBAHASAN}

Penelitian ini menggunakan pendekatan kuantitatif dengan desain korelasional. Pengumpulan data dilakukan melalui angket dan dokumentasi. Angket untuk memperoleh data tentang sikap tawakal dan kestabilan emosi. Sebagai sampel adalah siswa kelas XI MAN 1 Metro yang berjumlah 65 siswa. Skor hasil angket kemudian dikonversikan menjadi nila dengan hasil sikap tawakal nilai terendah 67 dan tertinggi 95 dengan nilai rata-rata 82,25. Sedangkan kestabilan emosi nilai terendah 79 dan tertinggi 97 dengan nilai rata-rata 89,57. Berikut hasil deskriptif data angket:

\begin{tabular}{|l|r|r|r|r|r|r|r|}
\hline & \multicolumn{1}{|c|}{ N } & \multicolumn{1}{|c|}{ Minimum } & Maximum & \multicolumn{2}{|c|}{ Mean } & Std. Deviation & Variance \\
\cline { 2 - 8 } & Statistic & Statistic & Statistic & Statistic & Std. Error & \multicolumn{1}{c|}{ Statistic } & Statistic \\
\hline SikapTawakal & 65 & 67 & 95 & 82.25 & .670 & 5.406 & 29.220 \\
KestabilanEmosi & 65 & 79 & 97 & 89.57 & .578 & 4.660 & 21.718 \\
ValidN (listwise) & 65 & & & & & & \\
\hline
\end{tabular}

Selanjutnya dilakukan uji hipotesis dengan menggunakan teknik analisa data korelasi product moment dengan bantuan SPSS 16. Sebelum menghitung nilai korelasi product moment, terlebih dahulu dirumuskan hipotesis, yaitu:
Ha : Ada pengaruh yang signifikan antara sikap tawakal terhadap kestabilan emosi siswa

Ho : Tidak ada pengaruh yang signifikan antara sikap tawakal terhadap kestabilan emosi siswa

Untuk menguji hipotesis menggunakan korelasi product moment terlebih dahulu dilakukan uji prasyarat, yaitu uji normalitas dan uji homogenitas. Hipotesis dalam uji normalitas yaitu: $\mathrm{H}_{0}=\quad$ Data terdistribusi normal dan $\mathrm{H}_{\mathrm{i}}=$ Data tidak terdistribusi normal. $\mathrm{H}_{0}$ diterima dan $\mathrm{H}_{\mathrm{i}}$ ditolak apabila nilai signifikansi $>0,05$ dan $\mathrm{H}_{0}$ ditolak dan $\mathrm{H}_{\mathrm{i}}$ diterima apabila nilai signifikansi $<0,05$. Berikut ini hasil analisis uji normalitas data yaitu:

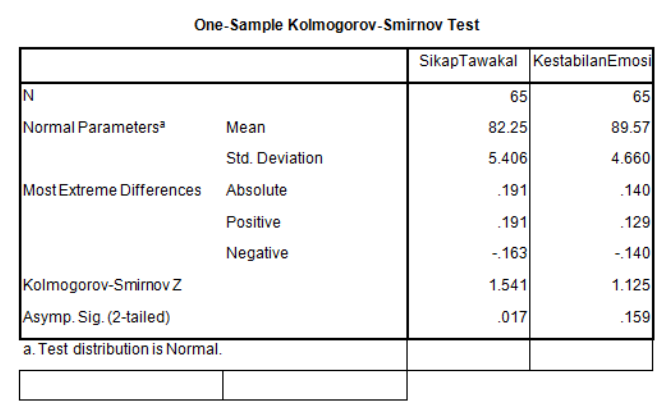

Berdasarkan hasil KolmogorovSmirnov di atas diketahui 1,541>0,05 dan $1,125>0,05$ sehingga data tiap kelompok berdistribusi normal. Adapun hipotesis untuk homogenitas adalah: $\mathrm{H}_{0} \quad=$ Matriks varians hasil angket homogen dan $\mathrm{H}_{\mathrm{i}} \quad=$ Matriks varians hasil angket tidak homogen. $\mathrm{H}_{0}$ diterima dan $\mathrm{H}_{\mathrm{i}}$ ditolak apabila nilai signifikansi $>0,05$ dan $\mathrm{H}_{0}$ ditolak dan $\mathrm{H}_{\mathrm{i}}$ diterima apabila nilai signifikansi < 0,05 . Berikut ini hasil analisis uji normalitas data yaitu: 
Test of Homogeneity of Variances

KestabilanEmosi

\begin{tabular}{|c|c|c|c|}
\hline Levene Statistic & df1 & df2 & Sig. \\
\hline 2.627 & 3 & 58 & .059 \\
\hline
\end{tabular}

Berdasarkan hasil pengujian diperoleh signifikansi yang lebih besar dari nilai alpha yang ditetapkan, yaitu $5 \%(0,05)$, yaitu 0,059 , yang berarti $\mathrm{H}_{0}$ diterima dan $\mathrm{H}_{\mathrm{i}}$ ditolak, sehingga dapat disimpulkan bahwa matriks varians angket homogen. Setelah hasil uji prasyarat normalitas dan homogenitas terpenuhi, langkah selanjutnya adalah uji hipotesis. Berdasarkan uji korelasi product moment dengan bantuan SPSS 16 diperoleh output SPSS sebagai berikut:

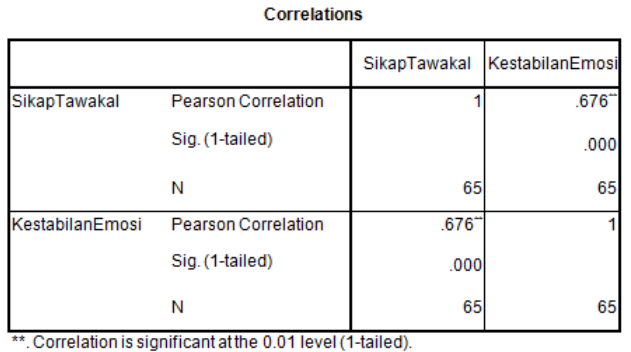

Berdasarkan hasil output SPSS di atas diperoleh $\mathrm{r}_{\text {hitung }}$ sebesar 0,676. Jika dibandingkan dengan nilai $r_{\text {tabel }}$ pada $\mathrm{df}$ 63 dengan taraf signifikansi 5\% yaitu 2,232 maka $r_{\text {hitung }}=0,676>r_{\text {tabel }}=$ 2,29. Diketahui juga nilai signifikansi untuk nilai $\mathrm{r}$ adalah 0,000 artinya $0,000<0,05$ yang berarti $\mathrm{H}_{0}$ ditolak dan $\mathrm{H}_{\mathrm{i}}$ diterima. Dengan demikan ada pengaruh antara sikap tawakal terhadap kestabilan emosi siswa, sehingga dapat disimpulkan bahwa semakin tinggi sikap tawakal maka semakin tinggi kestabilan emosi siswa. Sebaliknya semakin rendah sikap tawakal, maka semakin rendah kestabilan emosi siswa.

Sikap tawakal dapat mempengaruhi kestabilan emosi karena sikap tawakal memberi ketenangan jiwa dan ketenteraman hati. Sikap tawakal merupakan salah satu sikap keagamaan yang penting dimiliki oleh setiap muslim, terutama di masa sekarang, yaitu masa kemajuan ilmu pengetahuan dan teknologi yang telah menyebabkan perubahan nilai-nilai kehidupan. Sikap tawakal ini penting dimiliki karena sikap tawakal yang mampu membawa seseorang kepada kepasrahan kepada Sang Khalik. Ketika seseorang telah memiliki sikap kepasrahan yang penuh kepada Allah karena yakin akan jaminan dari Allah maka dia akan ridho terhadap segala sesuatu yang terjadi. Inilah yang disebut dengan sikap tawakal dan tentu saja bukannya suatu kepasarahan yang tanpa usaha melainkan kepasrahan yang disertai dengan suatu usaha (ikhtiar),

Ketika orang bertawakal maka dengan keimanan yang teguh dan kuat serta berkeyakinan bahwa Allah memberikan jaminan tentu akan menimbulkan rasa optimis, berani, dan tenteram. Sehingga dia akan memunculkan sikap yang baik dan mampu menjadi anggota masyarakat yang baik. Dengan adanya sikap yang positif orang akan dapat mengendalikan emosi atau dapat menjaga kestabilan emosinya. Emosi ini merupakan bagian yang tidak terpisahkan dari akan muncul ketika manusia. Emosi ini akan muncul ketika orang dihadapkan pada situasi dan 
kondisi tertentu. Secara umum, emosi yang positif akan muncul ketika dihadapkan pada situasi dan kondisi yang menyenangkan dan sebaliknya emosi yang negatif akan muncul ketika orang dihadapkan pada situasi dan kondisi yang tidak menyenangkan. Namun, bagi orang yang memiliki kestabilan emosi, ia mampu mengendalikan emosinya sehingga yang muncul adalah emosi yang positif meskipun dihadapkan pada situasi dan kondisi yang tidak menyenangkan.

Apabila seseorang benar-benar mengamalkan sikap tawakal ini, maka akan menumbuhkan kestabilan emosi. orang yang memiliki sikap tawakal dia akan selalu percaya diri, optimis, tenang, mampu menyalurkan emosi secara tepat, serta mampu beradaptasi dengan lingkungannya ketika ia menghadapi berbagai masalah. Allah akan membuatnya nyaman dan tenang dari sesuatu yang ditakuti dan dikhawatirkannya. Di antara buah tawakal adalah mendatangkan keberanian dan kekuatan hati.

\section{SIMPULAN}

Berdasarkan hasil analisa data dan pembahasan dapat disimpulkan bahwa ada pengaruh antara sikap tawakal terhadap kestabilan emosi siswa. Hal ini membuktikan bahwa semakin tinggi sikap tawakal maka semakin tinggi kestabilan emosi siswa. Sebaliknya semakin rendah sikap tawakal, maka semakin rendah kestabilan emosi siswa. Sikap tawakal penting dimiliki karena melalui sikap tawakal seseorang bisa sepenuhnya memasrahkan diri kepada Allah.
Kepasrahan yang tinggi kepada Allah memunculkan ketenangan dan ketenteraman hati. Ketenangan dan ketenteraman hati menjadikan emosi seseorang stabil.

\section{DAFTAR PUSTAKA}

Dadang Hawari, Al-Qur'an : Ilmu Kedokteran Jiwa dan Kesehatan Jiwa, Jakarta: Dana Bhakti Prima Yasa, 1996

Al-Jauzi, Al-Ruh fi Kalam ala Arwah Al-Amwat wa Al-Ahya' bidalail min Al-Kitab wa Al-Sunnah, 1975

http://repository.upi.edu/operator/uploa d/s_ppb_0608965_chapter3.pdf http://www.tawakal.or.id/arti-maknatawakal/

M. Yatimin Abdullah, Studi Akhlak Dalam Perspektif Al-Qur'an, Jakarta : Amzah, 2007

Nurcholish Madjid, Islam Doktrin dan Peradaban, Jakarta: Yayasan Wakaf Paramadina, 1995

Al-Jauzi, Tahdzib Madarijis Salikin,tt

Didiek Ahmad Supadie, Pengantar Studi Islam, Jakarta: Rajawali Press, 2011

Sa'id Hawwa, Al Islam Jilid 1, terjemahan Abu Ridho, Aunur Rafiq Shaleh Tamhid, Jakarta: Al-I'tishom, 2001

Yunahar Ilyas, Kuliah Aqidah Islam, Yogyakarta: LPPI Universitas Muhammadiyah Yogyakarta, 1993

Abdullah bin Umar Ad-Dumaji, Rahasia Tawakal Dan Sebab Akibat, Terjemahan Kamaluddin 
Sa'diatuloharamaini, Jakarta :

Pustaka Azzam, 2000

Sarlito Wirawan Sarwono, Pengantar

Umum Psikologi, Jakarta: Bulan

Bintang, 1976

Triantoro Safaria dan Nofrans Eka

Saputra, Manajemen Emosi

Sebuah panduan Cerdas

Bagaimana Mengelola Emosi

Positif Dalam Hidup Anda,

Jakarta: Bumi Aksara, 2009

Bimo Walgito, Pengantar Psikologi

Umum, Yogyakarta: Andi Offset, 1990 